\title{
PENERAPAN TEKNOLOGI PETERNAKAN SEBAGAI UPAYA PENINGKATAN PRODUKSI TERNAK SAPI POTONG DI DESA PENFUI TIMUR, KECAMATAN KUPANG TENGAH, KABUPATEN KUPANG
}

\author{
Meity Laut*, Aji Winarso*, Nemay Anggadewi Ndaong*, Imanuel Benu ${ }^{+}$ \\ *Fakultas Kedokteran Hewan, Universitas Nusa Cendana \\ ${ }^{+}$Fakultas Peternakan, Universitas Nusa Cendana \\ E-mail: $\underline{\text { laut.mm@staf.undana.ac.id }}$
}

\begin{abstract}
ABSTRAK
Program Kemitraan Masyarakat kelompok ternak sapi bertujuan untuk meningkatkan pengetahuan dan ketrampilan anggota mitra kelompok ternak di desa Penfui Timur tentang pemanfaatan teknologi peternakan untuk meningkatkan produktivitas ternak sapi dan menciptakan kemandirian ekonomi mitra. Kekurangan pakan berkualitas pada musim kemarau, terbatasnya lahan penggembalaan, tingkat kesakitan dan kematian ternak pada musim hujan yang cukup tinggi, terbatasnya akses layanan kesehatan ternak dan kurangnya pengetahuan peternak dalam pengolahan pakan dan limbah peternakan, merupakan masalah yang dihadapi mitra. Limbah peternakan berupa kotoran ternak hanya dibiarkan teronggok diluar kandang tanpa adanya pengolahan lebih lanjut. Tujuan dari kegiatan ini adalah untuk mengenalkan teknologi pengolahan jerami dengan amoniasi dan fermentasi serta pembuatan bokashi dengan memanfaatkan limbah peternakan. Metode yang digunakan dalam kegiatan PKM ini adalah penyuluhan, pelatihan dan demonstrasi serta pendampingan pada kelompok mitra. Hasil dari kegiatan ini adalah mitra mampu dan terampil membuat pakan jerami secara amoniasi dan fermentasi serta memproduksi bokashi. Amoniasi dan fermentasi jerami yang dihasilkan berkualitas baik yang ditunjukkan dengan warna coklat, tekstur lebih lunak disertai aroma seperti tape. Olahan jerami ini memiliki palatabilitas yang baik ditunjukkan dengan cepatnya respon ternak untuk konsumsi pada saat diberikan oleh peternak. Pupuk bokashi yang dihasilkan dari tahap pelatihan laris terjual sehingga mitra memproduksi lagi setiap minggu. Beberapa anggota kelompok mitra langsung mengaplikasikan pupuk bokashi pada tanaman dan kebun sayur mereka. Kesimpulan: teknologi pengolahan jerami dan pembuatan pupuk bokashi telah diterima dengan baik oleh mitra dan diterapkan sebagai solusi keterbatasan hijauan pada musim kemarau serta meningkatkan ekonomi peternak.
\end{abstract}

Kata kunci: bokashi, silase, amoniasi jerami, kemandirian ekonomi 


\section{PENDAHULUAN}

Beternak sapi bagi kelompok ternak sapi di desa Penfui Timur yang memiliki anggota 15 orang, dengan pekerjaan utama anggota kelompok adalah petani peternak. Setiap peternak rata - rata memiliki 3-4 ekor ternak sapi yang dipelihara dihalaman rumah masing - masing. Jenis atau bangsa sapi yang dipelihara oleh kelompok ini adalah sapi Bali (Bos sondaicus). Kandang yang dimiliki peternak adalah kandang sederhana dan terbuka, tidak beratap, tidak dilengkapi dengan tempat pakan dan air minum serta saluran pembuangan kotoran. Sistim pemeliharaan sapi yang diterapkan adalah semi-intensif, dimana sapi betina dilepaskan pada pagi untuk merumput di padang penggembalaan sepanjang hari dan dimasukkan kembali ke kandang pada sore harinya. Sedangkan sapi jantan dipelihara dengan tujuan paronisasi sehingga hanya dikandangkan (atau ditambatkan pada sebatang pohon) sepanjang hari dan pakan disediakan didalam kandang. Pakan yang disediakan berupa jerami padi kering yang diselingi dengan hijauan. Pakan hijauan yang diberikan pada ternak umumnya adalah daun lamtoro (Leucaena leucocephala), daun turi (Sesbania grandiflora), dan daun gamal (Gliricidia sepium) yang diperoleh dari area disekitar desa.

Ternak merupakan bagian penting bagi masyarakat di NTT. Tidak dapat dipungkiri fungsi ternak dalam sosio-cultural masyarakat NTT. Namun, kekurangan pakan dalam kuantitas dan kualitas menjadi masalah utama yang mengancam produktivitas ternak di NTT (Bamualim dan Wirdahayati, 2003). Kekurangan pakan yang berkualitas mempengaruhi kesusksesan suatu usaha peternakan. Selain itu, manajemen pemeliharaan yang masih semi-intensif dengan kondisi kandang yang sederhana menyebabkan kotoran ternak hanya dibiarkan menumpuk diluar kandang. Hal ini dapat menjadi sumber penularan penyakit parasit pada ternak seperti kecacingan dan miasis serta pencemaran lingkungan (Kementan, 2014). Kecacingan atau infestasi parasit (cacing) tidak langsung membunuh ternak namun menyebabkan gangguan pertumbuhan pada pedet, penurunan produksi ternak dan kerugian berupa biaya pengobatan yang lebih besar (Corwin, 1997). Selain itu, ternak yang diinfestasi parasit memiliki sistem kekebalan tubuh tidak efektif dalam menghalau infeksi patogen penyebab penyakit. Akibatnya, ternak mudah diinfeksi oleh patogen dan dapat menyebabkan kematian ternak serta potensi penyebaran penyakit pada ternak lain.

Berdasarkan analisis situasi diatas, usaha ternak sapi di kelompok mitra memiliki potensi untuk dikembangkan dengan terlebih dahulu mengatasi faktor penghambat diatas. Pelaksanaan PKM ternak sapi di desa Penfui Timur merupakan bentuk upaya pemberdayaan kelompok peternak yang bertujuan memberikan pengetahuan dan ketrampilan serta 
menciptakan kemandirian ekonomi peternak melalui pembuatan pakan alternatif dengan teknologi fermentasi dan amoniasi jerami serta pembuatan dan produksi bokashi yang dapat berkontribusi langsung terhadap peningkatan ekonomi peternak.

\section{MASALAH}

Masalah yang dihadapi oleh sebagian besar peternak dalam kelompok mitra secara umum adalah adalah sebagai berikut:

1. Beternak sapi masih dianggap sebagai usaha sampingan dan memenuhi kebutuhan sosio cultural

2. Pengetahuan dan ketrampilan peternak yang terbatas mengenai manajemen pemeliharaan ternak sapi modern termasuk ketrampilan pengolahan pakan sebagai alternatif dalam musim kemarau

3. Pengetahuan dan ketrampilan peternak yang terbatas mengenai pemanfaatn limbah peternakan dan pertanian

4. Terbatasnya lahan penggembalaan ternak seiring dengan pengembangan desa Penfui Timur sebagai area hunian baru.

\section{METODE PELAKSANAAN}

Kegiatan PKM di desa Penfui Timur dilaksanakan selama 8 bulan, dimulai dari bulan Maret 2018 hingga bulan Oktober 2018. Kegiatan - kegiatan yang dilakukan oleh tim pelaksana sebagai solusi atas masalah mitra adalah:

1. Pertemuan antara tim pelaksana dengan kelompok mitra

2. Penyuluhan mengenai manajemen kesehatan ternak sapi potong di lahan kering dan pengendalian penyakit parasit pada ternak sapi khas lahan kering

3. Penyuluhan mengenai jenis-jenis hijauan pakan ternak dilahan kering yang memiliki khasiat antihelmintik

4. Penyuluhan, pelatihan dan demonstrasi pengenalan teknologi pengolahan jerami dengan amoniasi dan fermentasi sebagai pakan alternatif pada musim kemarau.

5. Pelatihan dan demonstrasi pembuatan pupuk bokashi

6. Evaluasi hasil pembuatan amoniase jerami, silase dan pupuk bokashi

7. Promosi dan penjualan pupuk bokashi hasil produksi mitra.

Tahapan kegiatan yang telah dilaksanakan membawa dampak positif bagi tim pelaksana pengabdian dan mitra dimana terjalin relasi yang baik, adanya bantuan modal dan fasilitas 
untuk produksi pupuk bokashi dan pakan alternatif, serta adanya lahan pembelajaran bagi mahasiswa FKH Undana.

\section{HASIL YANG DICAPAI}

Kegiatan PKM ini secara umum berjalan dengan baik ditandai dengan diterimanya teknologi yang diperkenalkan oleh tim kepada anggota kelompok mitra. Bahkan kelompok mitra sudah mulai melakukan produksi pupuk bokashi secara rutin setiap minggu. Adapun tahapan kegiatan dan hasil yang dicapai diuraikan seperti berikut.

\section{Pertemuan dengan Kelompok Mitra}

Kegiatan PKM diawali dengan pertemuan antara tim pelaksana dan kelompok mitra untuk sosialisasi rencana kegiatan yang akan dilakukan sekaligus berkoordinasi untuk kelancaran kegiatan - kegiatan tersebut. Dalam pertemuan juga dibahas dan disepakati jadwal dan tempat pelaksanaan kegiatan.

\section{Penyuluhan}

Kegiatan penyuluhan dilakukan melalui penyampaian materi secara ceramah lapangan oleh tim pelaksana diikuti dengan sesi tanya jawab. Penyuluhan diikuti oleh semua anggota kelompok mitra serta mahasiswa FKH Undana. Keterlibatan mahasiswa bertujuan agar mereka dapat melihat dan mengalami langsung solusi yang diberikan untuk mengatasi masalah yang dihadapi mitra. Selain itu, kegiatan ini juga menjadi kesempatan bagi mahasiwa untuk menerapkan teori yang telah dipelajari di kampus, seperti teknik berkomunikasi dengan peternak, menyampaikan solusi atas masalah yang dihadapi oleh peternak sebagai klien dan sebagainya. Antusiasme masyarakat terlihat dalam sesi diskusi dengan banyaknya pertanyaan kepada tim. Penyuluhan dan diskusi dengan mitra berlangsung selama 2 jam. Walaupun materi telah disampaikan sesuai topik yang direncanakan, namun dalam sesi diskusi masyarakat juga bertanya mengenai kegagalan kawin alami dan kawin buatan pada ternak babi peliharaannya, penanganan limbah kotoran ternak babi, angka kesakitan hewan bahkan kematian pada awal musim hujan, peluang usaha dan lain sebagainya. 

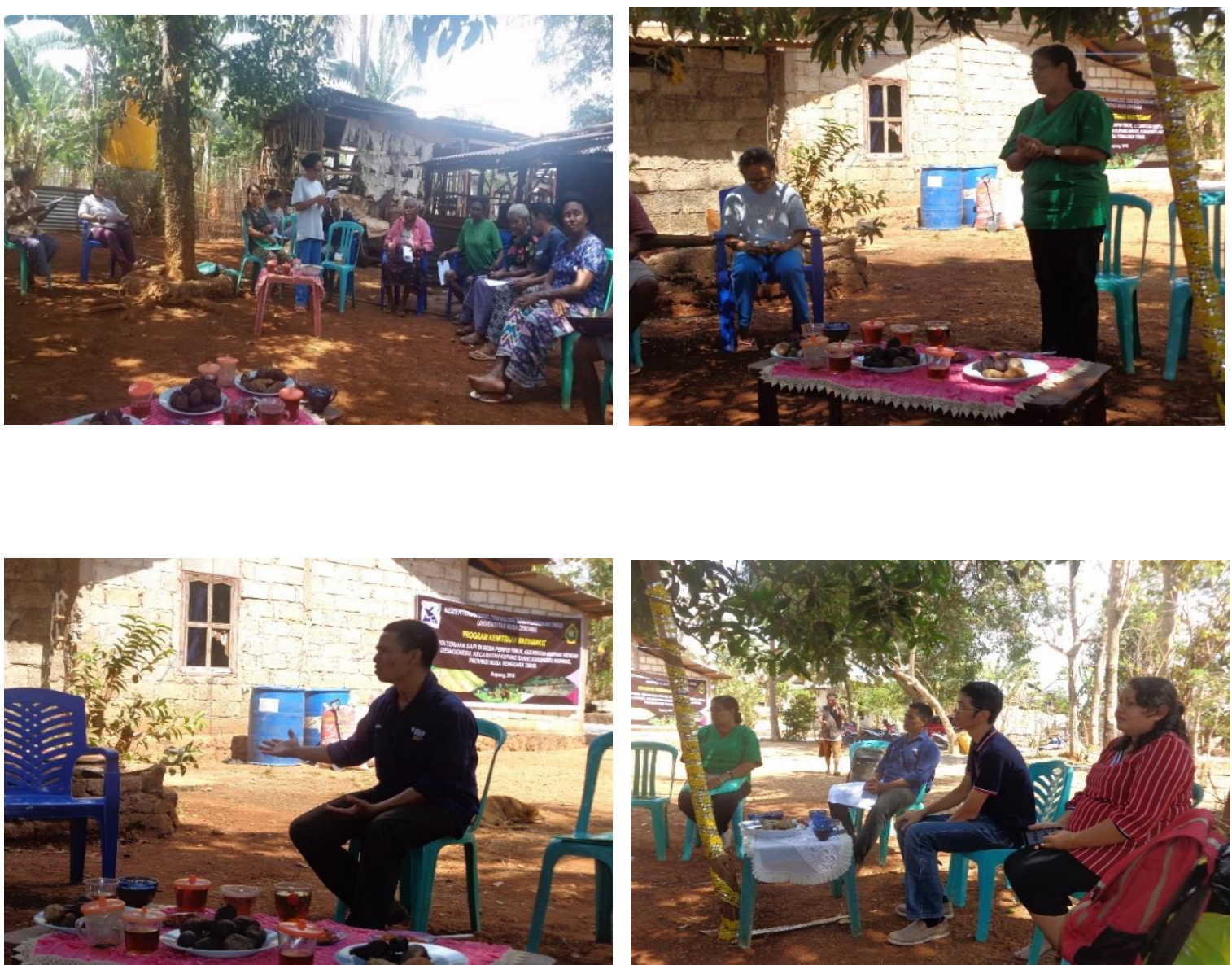

Gambar 1. Suasana Penyuluhan dan Diskusi dengan Mitra di desa Penfui Timur

\section{Pelatihan dan Demonstrasi}

Tahap ini meliputi pembuatan silase, amoniasi jerami dan pupuk bokashi. Materi pelatihan disajikan dalam bentuk poster berwarna dan berukuran A4, dilengkapi dengan gambargambar sehingga menarik dan mudah dipahami oleh mitra. Tim pelaksana bersama mitra dan mahasiswa bekerjasama dalam mempersiapkan bahan pelatihan seperti mencacah jerami, membakar sekam, melarutkan EM4 dan gula lontar serta menyiapkan dedak dan dedaunan kering. Tahapan demi tahapan pembuatan pakan alternatif dan bokashi dijelaskan dengan rinci dan perlahan - lahan sehingga mudah diikuti oleh masyarakat. Masyarakat terlihat sangat antusias dengan pelatihan ini sehingga banyak mengajukan pertanyaan kepada anggota tim yang melakukan pelatihan.

\section{Pembuatan Silase}

Silase adalah bahan pakan yang dihasilkan melalui proses fermentasi yang terkontrol (anaerobic fermentation) dari hijauan tanaman atau limbah pertanian dengan kadar air yang tinggi. Hampir semua tanaman dapat diawetkan sebagai silase, namun pada 
umumnya yang digunakan adalah rumput, legum dan biji-bijian khususnya gandum dan jagung. Ensilase adalah proses fermentasi silase, sedangkan tempat penyimpanan silase di sebut silo (McDonald dkk., 2011). Prinsip dasar pembuatan silase adalah untuk memanfaatkan hijauan yang tersedia melimpah sepanjang musim hujan yang diawetkan untuk menjamin ketersediaan pakan bagi ternak sepanjang musim kemarau. Bahan pakan seperti rumput atau hijauan (leguminose) yang dipanen atau dipotong harus dikeringkan dibawah sinar matahari/diangin-anginkan (60\% kandungan air) sehingga tidak terjadi kerusakan atau pembusukan selama proses penyimpanan. Silase berasal dari hijauan makanan ternak ataupun limbah pertanian yang diawetkan dalam keadaan segar dan disimpan dalam silo (bisa berupa drum atau plastik) melalui fermentasi secara anaerob melibatkan mikroba yang membentuk asam susu yang hidup secara anaerob pada $\mathrm{pH} 4$. Fermentasi dimulai saat oksigen telah habis digunakan oleh sel tanaman. Mikroba menggunakan karbohidrat mudah larut untuk menghasilkan asam laktat dalam menurunkan $\mathrm{pH}$ silase.

\section{Bahan yang dibutuhkan:}

- Hijauan/limbah pertanian: rumput gajah, rumput lapangan, batang jagung, daun gamal, jerami padi, sorgum dan lain-lain.

- Konsentrat: Dedak halus (5\% bahan silase. Contohnya $5 \%$ x $100 \mathrm{~kg}=5 \mathrm{~kg}$ ), tepung jagung ( $3 \%$ bahan silase; $3 \%$ x $100 \mathrm{~kg}=3 \mathrm{~kg}$ ), ampas tahu dan lain-lain

- Bahan tambahan (additive) berupa molasses (3\% bahan silase. Contohnya 3\% x 100 $\mathrm{kg}=2,5-3 \mathrm{~kg}$ ); EM4 ditambahkan sebanyak 2 tutup botol.

- Formulasi pakan silase komplit dari tanaman pakan ternak: Konsentrat: bahan additive adalah 70\%:20\%:10\% atau 60\%: 30\%: 10\% (Sofyan dan Febrisiantosa, 2007)

- Media penyimpanan (silo/drum/plastik)

\section{Cara pembuatan silase:}

- Potong atau cacah jerami atau hijauan dengan ukuran 5-10 cm agar mudah dimasukkan kedalam drum, mengurangi ruang udara dalam silo dan mudah dipadatkan.

- Campur konsentrat dan bahan tambahan secara homogen kemudian taburkan pada jerami.

- Campur dan aduk merata campuran jerami dan bahan tambahan 
- Masukan campuran pakan tersebut ke dalam drum dan padatkan (diinjak-injak sampai padat untuk memastikan tidak ada rongga udara)

- Tutup rapat media penyimpanan

- Silase pakan berlangsung selama 21 hari. Pada proses pembuatan silase yang baik bisa memungkinkan masa penyimpanan silase 6 bulan hingga 1 tahun.

\section{Pembuatan Amoniasi Jerami Padi}

Ketersediaan pakan baik secara kuantitas maupun kualitas menentukan keberhasilan suatu usaha peternakan. Oleh karena itu, penting bagi peternak untuk memastikan ketersediaan pakan bagi ternak peliharaannya. Jerami padi kering yang diberikan tanpa adanya pengolahan terlebih dahulu diketahui memiliki kandungan serat kasar yang tinggi dan ikatan lignoselulosa yang kuat sehingga sulit dicerna oleh ternak (Trisnadewi dkk, 2011). Selain itu, kandungan nutrisi dari jerami seperti protein, mineral - mineral penting dan vitamin sangat rendah bagi pertumbuhan, perkembangan dan reproduksi (Preston dan Leng, 1987). Untuk meningkatkan kecernaan dan kandungan nutrisi jerami padi, diperlukan teknologi pengolahan yang dikenal dengan amoniasi. Amoniasi adalah perlakuan alkali jerami dengan penambahan urea yang berfungsi untuk melemahkan ikatan lignoselulosa sehingga meningkatkan kecernaannya. Jerami padi yang diberikan urea dan disimpan selama 4 minggu dapat meningkatkan daya cerna hingga 43,6\% dan kandungan nitrogen total menjadi 1,55\%. Amoniasi juga bertujuan untuk mengawetkan jerami atau batang jagung sehingga tidak rusak atau berjamur selama proses penyimpanan (Sudana, 1984).

\section{Bahan yang dibutuhkan:}

- Jerami padi kering

- Urea (4-5\% berat jerami atau 4-5 kg untuk setiap $100 \mathrm{~kg}$ jerami padi)

- Air (50-60\% berat jerami atau 50-60 liter air untuk setiap $100 \mathrm{~kg}$ jerami padi)

\section{Prosedur:}

- Potong atau cacah jerami padi

- Campurkan air dan urea sambil diaduk untuk memastikan urea larut dalam air

- Masukan jerami ke dalam media (drum) dan disiram dengan larutan urea. Pastikan jerami dalam media terisi secara padat (bisa dilakukan dengan menginjak-injak).

- Tutup drum dengan rapat 


\section{Pembuatan Pupuk Bokashi}

Kotoran ternak sapi yang dibiarkan menumpuk di luar kandang milik kelompok mitra di desa Penfui Timur, berpotensi sebagai sumber penyakit dan pencemaran lingkungan. Kotoran tersebut dapat diolah menjadi pupuk bokashi. Bokashi adalah pupuk kompos yang dihasilkan melalui proses fermentasi dengan memanfaatkan aktivitas empat jenis mikroba (effective microorganisms atau EM4) yaitu bakteri fermentasi (Genus Lactobacillus), bakteri fotosintetik Actinomycetes, jamur fermentasi dan ragi. Keuntungan menggunakan EM4 adalah menghasilkan bokashi dalam waktu singkat dibandingkan dengan cara konvensional. Selain kotoran ternak, bahan untuk pembuatan bokashi mudah diperoleh yaitu jerami sisa pakan ternak yang terbuang dalam kandang, serasa atau daun daun kering dipekarangan rumah, sekam yang bisa diperoleh di tempat penggilingan padi, ataupun serbuk gergaji pada tempat produksi mebel. Bahan lain yang dapat ditambahkan adalah dedak padi sebagai sumber nutrisi bagi mikroba dalam proses dekomposisi. Pupuk Bokashi dapat digunakan untuk menyuburkan tanah dengan menekan pertumbuhan patogen dalam tanah sehingga dapat meningkatkan pertumbuhan dan produksi tanaman.

\section{Bahan-bahan yang dibutuhkan (untuk produksi $250 \mathrm{~kg}$ bokashi):}

- $50 \mathrm{~kg}$ jerami/hijauan/serasah

- $150 \mathrm{~kg}$ kotoran ternak (kering)

- $12.5 \mathrm{~kg}$ dedak/serbuk gergaji

- $\quad 12.5 \mathrm{~kg}$ arang sekam

- $25 \mathrm{~kg}$ top soil/humus

- 250 ml larutan EM4

- 250 gr gula pasir

\section{Prosedur:}

- Larutkan gula pasir dan larutan EM4 dalam air

- Pupuk kandang, arang sekam dan dedak dicampur merata dan digundukan di atas tanah yang kering atau di atas lantai dengan ketinggian sekitar $15-20 \mathrm{~cm}$

- Siram larutan gula pasir dan EM4 secara perlahan ke dalam adonan sambil dicampur merata

- Bokashi yang baik adalah bila adonan dikepal air tidak menetes dan bila kepalan tangan dilepas maka adonan tidak pecah

- Tutup dengan terpal atau plastik selama 4-7 hari 
- Pertahankan suhu maksimal $50^{\circ} \mathrm{C}$. Apabila suhunya lebih maka turunkan dengan cara membolak-balik adonan atau campuran bokashi (suhu yang tinggi dapat menyebabkan kerusakan bokashi karena terjadi pembusukan)

- Pemeriksaan suhu bisa dilakukan setiap 5 jam sekali

- Setelah 4-7 hari bokashi telah selesai terfermentasi dan siap digunakan sebagai pupuk organik

Dari kegiatan pelatihan dan demonstrasi dihasilkan $250 \mathrm{~kg}$ bokashi yang kemudian terjual pada saat dipanen seminggu kemudian. Anggota kelompok mitra kemudian memproduksi lagi bokashi sebanyak $500 \mathrm{~kg}$. Kegiatan produksi bokashi kemudian rutin dilakukan oleh peternak mitra setiap minggunya.
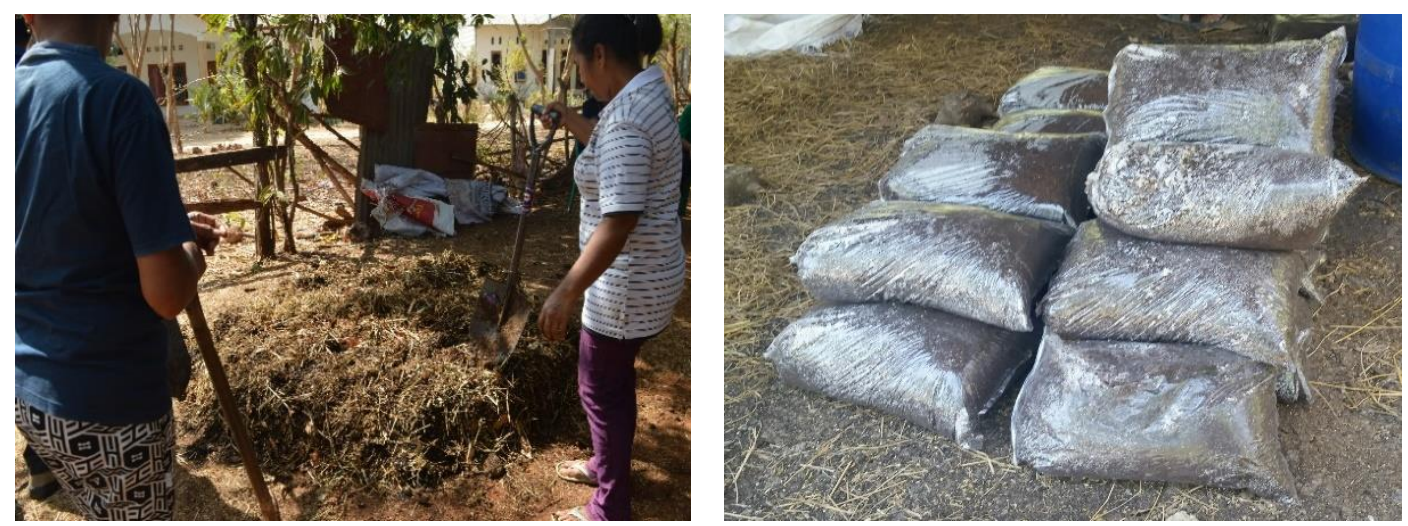

Gambar 2. Produksi pupuk Bokashi oleh Kelompok Mitra

\section{KESIMPULAN}

Teknologi pengolahan jerami berupa amoniasi dan silase serta pembuatan pupuk bokashi yang diperkenalkan dan diajarkan telah diterima dan diaplikasikan dengan baik oleh kelompok mitra. Hal ini menjadi sangat penting dalam mendukung peningkatakan produksi ternak sapi dan kemandirian ekonomi peternak sapi di desa Penfui Timur.

\section{SARAN}

Agar peternak kelompok mitra terus melanjutkan produksi bokashi, pembuatan silase dan amoniase sehingga dapat mengatasi kesulitan pakan hijauan yang berkualitas di musim kemarau dan meningkatkan kesejahteraan peternak. 


\section{UCAPAN TERIMA KASIH}

Terima kasih disampaikan kepada Kementerian Riset, Teknologi dan Pendidikan Tinggi (KEMENRISTEK - DIKTI) yang telah menyetujui dan mendanai pelaksanaan Program Kemitraan Masyarakat (PKM) Tahun Anggaran 2018.

\section{DAFTAR PUSTAKA}

Bamualim A dan Wirdahayati RB. 2003. Nutrition and Management Strategies to Improve Bali Cattle Productivity in Nusa Tenggara. ACIAR Proceedings No. 110.

Corwin, RM. 1997. Economics of gastrointestinal parasitism of cattle. Veterinary Parasitology 72 (1997) 451-460.

Kementerian Pertanian Direktorat Jenderal Peternakan dan Kesehatan Hewan Direktorat Kesehatan Hewan. 2014. Manual penyakit hewan mamalia. Edisi 2. Subdit Pengamatan Penyakit Hewan Direktorat Kesehatan Hewan Direktorat Jenderal Peternakan dan Kesehatan Hewan Kementerian Pertanian

McDonald P, RA Edwards, JFD Greenhalgh, CA Morgan, LA Sinclair, dan RG Wilkinson. 2011. Animal nutrition. $7^{\text {th }}$ Ed. Pearson Education Ltd. Edinburgh Gate Harlow Essex CM 202JE England.

Preston, TR dan Leng, RA. 1987. Matching ruminant production systems with available resources in the tropics and subtropics. Penambul Books: Armidale, N.S.W.

Sofyan A dan Febrisiantosa A. 2007. Tingkatkan kualitas pakan ternak dengan silase komplit. UPT BPPTK-LIPI, Yogyakarta. Sumber: majalah INOVASI. Edisi 5 Desember 2007.

Trisnadewi, AAAS, NLG. Sumardani, BR Tanama Putri, IGLO Cakra, dan IGAI Aryani. 2011. Peningkatan kualitas jerami padi melalui penerapan teknologi amoniasi urea sebagai pakan sapi berkualitas di desa Bebalang Kabupaten Bangli. Udayana mengabdi 10 (2): 72 74 ISSN: 1412-0925

Sutrisno, CI, Sulistyanto, Widyati S, Nurwantoro, Mukodiningsih, S, Surahmanto, dan Tristiarti. 2006. Peningkatan Kualitas Jerami sebagai Pakan. Available from: URL : http:// www.dikti.org / p3m / abstrakHB / AbstrakHBO5.pdf. 